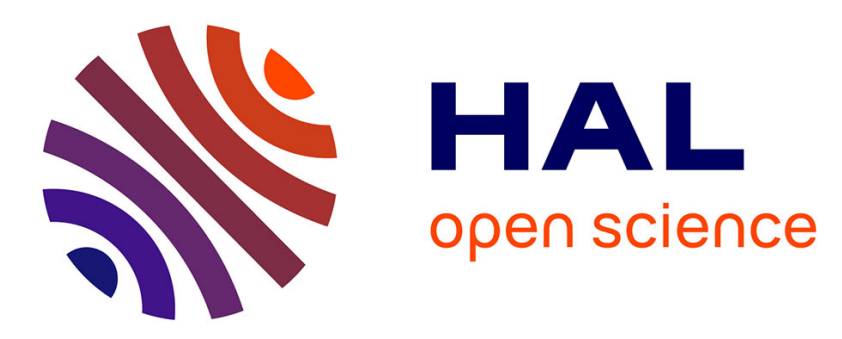

\title{
Inhibitor Formation in Congenital Hemophilia A: an Immunological Perspective
}

Sandrine Delignat, Julie Rayes, Jules Russick, Srinivas Kaveri, Sébastien Lacroix-Desmazes

\section{- To cite this version:}

Sandrine Delignat, Julie Rayes, Jules Russick, Srinivas Kaveri, Sébastien Lacroix-Desmazes. Inhibitor Formation in Congenital Hemophilia A: an Immunological Perspective. Seminars in Thrombosis and Hemostasis, 2018, 10.1055/s-0038-1657777 . hal-02328245

\section{HAL Id: hal-02328245 \\ https://hal.science/hal-02328245}

Submitted on 26 Oct 2019

HAL is a multi-disciplinary open access archive for the deposit and dissemination of scientific research documents, whether they are published or not. The documents may come from teaching and research institutions in France or abroad, or from public or private research centers.
L'archive ouverte pluridisciplinaire HAL, est destinée au dépôt et à la diffusion de documents scientifiques de niveau recherche, publiés ou non, émanant des établissements d'enseignement et de recherche français ou étrangers, des laboratoires publics ou privés. 
Inhibitor formation in congenital haemophilia A: an immunological perspective

Sandrine Delignat, PhD, Julie Rayes, PhD, Jules Russick, Srinivas V Kaveri, DVM, PhD, Sebastien Lacroix-Desmazes, $\mathrm{PhD}$, and The ABIRISK consortium

Centre de Recherche des Cordeliers, Université Pierre et Marie Curie - Paris 6, UMR S 1138, Paris, F-75006 France; Université Paris Descartes, UMR S 1138, Paris, F-75006 France; INSERM, U1138, Paris, F-75006 France

Corresponding author: Sébastien Lacroix-Desmazes, INSERM UMR S 1138 Equipe 16, Centre de Recherche des Cordeliers, Paris, F-75006 France - Tel: 0144278202 - Fax: 0144 2781 93. Sebastien.Lacroix-Desmazes@crc.jussieu.fr

Short Title: Inhibitor formation - immunological perspective

Keywords: Haemophilia A, factor VIII, immunogenicity 


\begin{abstract}
The immunogenicity of therapeutic factor VIII (FVIII) in patients with hemophilia A has been puzzling scientific and clinical communities for more than 3 decades. Indeed, the development of inhibitory antibodies to FVIII remains a major clinical challenge and is associated with enormous societal costs. Thus, the reasons for which a presumably innocuous, short-lived, intravenously administered glycoprotein triggers such a deleterious, long-lasting neutralizing immune response is an enigma. This review does not pretend to bring an answer to this challenging question. It will however summarize the latest findings regarding the molecular interactions at play in the recognition of FVIII by the immune cells, the validity of the proposed risk factors for FVIII allo-immunization, and the different solutions that allow induction of FVIII-specific tolerance in preclinical models of hemophilia A.
\end{abstract}




\section{Introduction}

Haemophilia A (HA) is an X-linked inherited disorder caused by a defect in the gene encoding coagulation factor VIII (FVIII). The disease is typically divided in three categories of severity based on the circulating levels of pro-coagulant FVIII detected in plasma. Haemophilia A is "mild" (5-40\% of residual FVIII compared to normal plasma), "moderate" $(1-5 \%)$ or "severe" $(<1 \%)$. The most efficient strategy to correct or prevent bleeding in the patients relies on the intravenous administration of exogenous therapeutic FVIII that is either plasma-derived (pdFVIII) or recombinant (rFVIII). Currently, the most serious complication of FVIII replacement therapy is the development of anti-FVIII antibodies with neutralizing properties that are referred to as "FVIII inhibitors". While anti-drug antibodies typically arise in $1-5 \%$ of the patients, FVIII inhibitors develop in up to $30 \%$ of the patients with HA. ${ }^{1}$ In addition, the intravenous route of administration is classically considered as nonimmunogenic. $^{2}$ The elevated rate of development of inhibitory antibodies to FVIII is thus intriguing from an immunological stand-point. Here, we will review the current knowledge on the anti-FVIII immune response with a specific focus on the molecular interactions at play in the recognition of FVIII by the cells of the innate and adaptive immune system and on the intuitively proposed risk factors for FVIII allo-immunization. The review will also propose a short summary of the different immuno-intervention approaches validated in preclinical models of HA to confer tolerance to exogenous FVIII.

\section{Dynamics of the anti-FVIII immune response}

\section{The primary immune response to therapeutic FVIII}

The development of FVIII inhibitors results from a classical allogenic immune response that is dependent on CD4 $\mathrm{T}$ cells. ${ }^{3}$ The implication of $\mathrm{T}$ cells has been suggested empirically in inhibitor-positive patients who became tolerant to exogenous FVIII following HIV infection. ${ }^{4}$ 
It was further suggested by the lack of anamnestic immune response to exogenous FVIII upon treatment using antagonist anti-CD40-ligand (CD40L) antibodies. ${ }^{5}$ The mandatory step for initiation of a $\mathrm{T}$ cell response is antigen recognition and internalization by a professional antigen presenting cells (APCs). After endocytosis, FVIII is cleaved into small peptides that associate with molecules of the major histocompatibility complex of class II (MHC class II) depending on their affinity. The APCs then migrate to secondary lymphoid organs such as spleen or lymph nodes to reach $\mathrm{T}$ cell-rich areas. Complexes of FVIII-derived peptide and MHC class II molecules are exposed at the surface of APCs and are presented to naïve CD4 T cells. The recognition of FVIII-derived peptide by the T-cell receptor (TCR) of $\mathrm{T}$ lymphocytes provides a first activation signal (signal 1). Additional signalization implicating interactions of ligands and receptors at the surface of T cells and APCs (signal 2), and presence of soluble pro-inflammatory stimuli such as cytokines (signal 3) are also required in the micro-environment to fully activate the FVIII-specific naïve T cells. Such signals involve at least interactions between CD40L expressed at the T cell surface with CD40 exposed on the APC membrane, ${ }^{6,7}$ as well as CD86 and CD28 expressed by APCs and T cells, respectively (Figure 1). ${ }^{8}$ Once activated, T cells migrate towards the B cell follicles. In general, humoral responses directed against proteins involve the follicular B cell pathway within secondary lymphoid organs..$^{9}$ The early phase of this activation pathway corresponds to an extrafollicular response where naïve $B$ cells that have internalized the antigen through their membrane immunoglobulin or B-cell receptor (BCR) present $\mathrm{CMH}$ II/peptide complexes to activated $\mathrm{T}$ cells. The formation of the T/B cell synapse triggers intracellular signaling that leads to the differentiation of follicular B cells into short-lived plasma cells that produce IgM or IgG of low affinity. ${ }^{9,10}$ During the late phase of the follicular B cell response, activated B cells re-enter the follicles to interact with follicular helper $\mathrm{T}$ cells and form germinal centers (GCs). ${ }^{9}$ GCs are specialized micro-environment for $\mathrm{T}$ and $\mathrm{B}$ cell interactions leading to the 
proliferation/selection of B cells and accumulation of somatic hypermutations in the genes encoding the variable regions of the BCRs. GCs responses generate memory B cells that are able to quickly differentiate into antibody secreting cells (ASCs) after re-exposition to the antigen. ${ }^{11}$ GCs associated responses also generate long-lived plasma cells. ${ }^{12}$ In the case of anti-FVIII immune responses, the presence of low affinity anti-FVIII antibodies has been documented in healthy donors, non-exposed patients to exogenous FVIII and inhibitornegative patients. ${ }^{13,14}$ It is conceivable that the production of such low affinity antibodies results from early extra-follicular responses. In contrast, the finding of high affinity anti-FVIII IgG4 observed in inhibitor-positive patients implicates the differentiation of follicular B cells involving formation of GCs and help from FVIII-specific follicular T cells. ${ }^{13-15}$

\section{The secondary immune response to therapeutic FVIII}

Primary responses involve naïve FVIII-specific $\mathrm{T}$ and $\mathrm{B}$ cells. In contrast, subsequent exposures of the organism to exogenous FVIII recruits FVIII-specific memory B cells generated during the primary immune response. Memory B cells are able to develop a faster and stronger immune response against FVIII than naïve B cells, and their recruitment leads to the production of high affinity neutralizing antibodies. ${ }^{10,14} \mathrm{~T}$ and $\mathrm{B}$ cell interactions are also essential during secondary anti-FVIII humoral responses in HA mice. The administration of an anti-CD40L monoclonal antibody to FVIII-deficient mice that have already developed a primary immune response to FVIII leads to GCs depletion after 24 hours. In addition, the repeated injection of FVIII concomitantly with an anti-CD40L antibody prevents the formation of new GCs and the production of anti-FVIII antibodies, while it does not allow induction of long-term tolerance. ${ }^{5}$ Thus, CD40-CD40L interactions play a crucial role in formation and maintenance of GCs during the secondary immune response to FVIII. AntiFVIII memory B cells are essentials to maintain long-term humoral response and to drive 
quick anamnestic response upon FVIII re-exposure. While memory B cells are preferentially located in lymphoid organs, Van Helden et al successfully detected circulating FVIII-specific B cells in inhibitor-positive HA patients. By incubating irradiated-murin thymoma EL4B5, that express human CD40L with CD19-positive B cells from patients during 9 to 10 days, they allowed the in vitro differentiation of memory B cells into ASCs. The presence of FVIIIspecific memory B cells was then tested by ELISpot assay. ${ }^{16}$ The frequency of circulating FVIII-specific memory B cells represented $0.05 \%$ to $0.24 \%$ of surface IgG-positive B cells. Importantly, the secondary immune response generates long-lived plasma cells that are likely to migrate to specific niches in the bone marrow. ${ }^{9,17}$ In FVIII-deficient mice, FVIII-specific plasma cells are detected in the bone-marrow from the third injection of FVIII where they survive for more than 22 weeks without any further FVIII injection. ${ }^{18}$

\section{Initiation of an anti-FVIII immune response}

\section{Antigen presenting cells}

Different types of APCs may be involved in the capture and endocytosis of therapeutic FVIII in patients. Among these, dendritic cells (DCs), macrophages, and B cells are the most probable candidates. The type of APCs at play depends on the immune status of the patients towards FVIII, in particular whether their organism has previously been exposed to exogenous FVIII or not. In previously untreated patients (PUPs), where the immune system never encountered FVIII, a role for naïve FVIII-specific B cells is very unlikely owing to their very low frequency. Recently, Zerra et al observed in FVIII-deficient mice the co-localization of exogenous FVIII in the marginal zone of the spleen at the level of a specialized B cell subset, marginal zone (MZ) B cells. MZ B cells express polyreactive B cell receptor and are located at the interface of blood circulation and immune system. The authors showed that the depletion of MZ B cells leads to a significant reduction of the anti-FVIII immune response. ${ }^{19}$ 
This observation may reflect the role of MZ B cells in trafficking FVIII from the MZ to B-cell follicles and to the CD4 T-cell and DC rich areas, rather than a direct role of MZ B cells in priming of naïve T cells. ${ }^{20}$ Besides, Archambault et al demonstrated, using a mouse model of conditional expression of MHC class II, that B cells are less prone than DCs to present antigens to naïve T cells during primary immune response. ${ }^{21}$

Macrophages are generally described as highly efficient phagocytic cells due to the expression of a myriad of endocytic receptors. In blood, macrophages circulate as monocytes and differentiate into macrophages after infiltrating tissues. Several specialized subpopulations of macrophages are present in the spleen. ${ }^{22}$ Interestingly, thirty minutes after intravenous injection, our seminal work had shown the co-localization of FVIII mostly with metallophillic and MZ macrophages in the MZ of the spleen of hemophilic mice. Depletion of splenic macrophages and $\mathrm{CD} 11 \mathrm{c}^{+} / \mathrm{CD} 8 \alpha^{-}$DCs by injection of clodronate-containing liposomes abrogated the anti-FVIII humoral response. ${ }^{23}$ As mentioned in the case of MZ B cells, this observation may reflect the role of MZ macrophages in cellular and molecular exchange between the $\mathrm{MZ}$ and the white pulp of the spleen in the initiation of antigen-specific immune responses. ${ }^{24}$ Of note, the ability of macrophages to express co-stimulation molecules and activate naïve CD4 T cells is lower than that of DCs. ${ }^{25,26}$

It is important to mention that techniques used to date to validate the role of different splenic APC subsets rely primarily on the physical elimination of the cells, either by targeting cells characterized with a high endocytosis capacity using chlodronate-containing liposomes or using depleting antibodies that target particular APC populations. Such approaches are not without consequences on the architecture of the $\mathrm{MZ}$ of the spleen ${ }^{27}$ and interpretation on whether the targeted APC subtype is at play in the initiation of the anti-FVIII immune response or whether the disrupted $\mathrm{MZ}$ splenic structure is an artefactual reason for the reduced onset of FVIII-specific immune responses is not clear. 
DCs are often described as 'sentinel' cells ${ }^{28}$ by virtue of their high plasticity. DCs circulate in the blood in an immature state, and several distinct sub-populations of DCs are present in different tissues. DCs are able to sample antigens and to simultaneously detect danger signals. Following their migration to secondary lymphoid organs, they orchestrate the outcome of Tcell presentation: depending on the nature of signals they sense in the micro-environment, they may promote T-cell inactivation and induction of immune tolerance or, on the contrary, T-cell priming and activation. Because of the central role of DCs in presenting antigen to naïve T cells, our group and others have used human immature monocytes-derived DCs (MODCs), an in vitro source of DCs, to investigate the capture and presentation of FVIII by APCs. MO-DCs are able to endocytose FVIII and to present FVIII-derived peptide to human FVIIIspecific T cell lines. ${ }^{29-31}$

\section{Endocytic receptors for FVIII}

Antigens may be internalized via three different ways: macropinocytosis, phagocytosis or receptors-dependent endocytosis. Macropinocytosis consists in the internalization of large quantities of soluble antigen by non-specific membrane invagination. On the basis of the low concentration of circulating FVIII, it is unlikely that FVIII is internalized by APCs through macropinocytosis. Phagocytosis consists in the capture of large soluble particles such as virus, bacteria or apoptotic cells. In the case of protein antigens, endocytosis occurs mostly by means of receptors. Receptors-dependent endocytosis is very efficient from a kinetic point of view and implicates defined motives on the glycoproteins; this allows the capture of antigens present at low concentrations in the surrounding environment. ${ }^{26}$ Since FVIII circulates mostly as a complex with its chaperon molecule von Willebrand factor (VWF), the internalization of FVIII may occur through endocytic receptors that bind VWF or FVIII itself. Indeed, several endocytic receptors for VWF and FVIII have been identified. ${ }^{32,33}$ The endocytosis of FVIII or 
the FVIII/VWF complex may lead to FVIII accumulation in lysosomes followed by its degradation, or to the trafficking of FVIII to the endosomal compartments and presentation of FVIII-derived peptide/MHC class II complex at the cell surface. The outcome of FVIII (catabolism or presentation to $\mathrm{T}$ cells) following its uptake depends on the site of internalization, the nature of APCs and the receptors that are involved in endocytosis. Currently, endocytic receptors that are known to bind to VWF and FVIII have been mostly involved in the clearance of VWF and/or FVIII. This review will focus mainly on endocytic receptors that have been shown to bind to FVIII (Table 1).

\section{Low density lipoprotein receptor family}

The role of the low-density lipoprotein-1 (LRP-1 or CD91) in FVIII catabolism has been documented in several studies. ${ }^{34,35}$ The physiological relevance of LRP-1 in FVIII clearance was demonstrated in a mouse model in which deletion of LRP-1 increased the endogenous plasma FVIII levels and FVIII half-life. ${ }^{36}$ Furthermore, epidemiological studies in human of two polymorphisms of the LRP-1-encoding gene have shown that this receptor modulates the levels of plasma FVIII. ${ }^{37}$ FVIII presents three potential binding sites to LRP-1:a low affinity site located in the $\mathrm{C} 2$ domain $^{34}$, and two high affinity sites situated in the A2 and A3 domains. ${ }^{38,39}$ Under physiological conditions, the binding region for LRP-1 on the heavy chain (A2 domain) is only exposed after proteolytic cleavage of FVIII. ${ }^{40}$ Thus, while intact FVIII only interacts with LRP-1 via its light chain, activated FVIII binds to LRP-1 through both its heavy and light chains. When VWF is complexed to FVIII, it interferes with the binding site on the light chain. ${ }^{34}$ In a scenario proposed by Sarafanov, the VWF/FVIII complex binds to heparan sulfate proteoglycans (HSPG), a component of the extracellular matrix, leading to the concentration of FVIII at the cell surface and dissociation of the VWF/FVIII complex, thus exposing the binding site on FVIII for LRP-1. ${ }^{41}$ More recently, 
Rastegarlari et al observed a direct interaction of VWF with LRP-1 at the surface of macrophages under shear stress conditions, thus highlighting another possible mechanism of binding of VWF/FVIII complex to LRP-1. ${ }^{42}$ While LRP-1 has been mostly involved in the catabolism of antigens, several studies have reported a role of LRP-1 in the development of immune response. ${ }^{43,44}$ Indeed, the binding of heat shock proteins (HSP) and proteins released by tumor cells to LRP-1 on APCs leads to their internalization and activation of nuclear factor kappa B (NF-kB) pathway, subsequently leading to the maturation of APCs and the secretion of pro-inflammatory cytokines and allowing the polarization of the T-cell response toward Th1 and Th17 profiles. ${ }^{43,45}$ Others receptors of the LDL-R family may contribute to FVIII uptake by APCs, since LDL-R interacts with FVIII and regulates the circulating FVIII levels in concert with LRP-1.46,47 Yet, a role for LRP-1 or others LDL-R in the initiation of antiFVIII immune response remains to be demonstrated, since an involvement of these receptors in FVIII uptake by MO-DCs has been excluded by several studies. ${ }^{31,48,49}$

\section{Asialoglycoprotein receptor}

The scavenger receptor asialoglycoprotein receptor (ASGPR) was reported to recognize $\beta$-Dgalactose and $\mathrm{N}$-acetyl-galactosamine residues that are predominantly exposed on the Bdomain of FVIII. ${ }^{50}$ Because no obvious differences in the half-life and immunogenicity of full-length FVIII and B domain deleted FVIII (BDD-FVIII) have been observed, the role of this receptor in FVIII catabolism or endocytosis by APCs remains to be determined.$^{51}$ In agreement with this, the use of galactose to saturate ASGPR had no effect on FVIII uptake by DCs. ${ }^{29}$ 
Recently, Pegon et al reported that sialic-acid binding immunoglobulin-like lectins-5 (Siglec5), a human receptor of the lectin family, binds to both VWF and FVIII. Siglec-5 recognizes sialic acid-ending polysaccharide chains. While binding of VWF to Siglec-5 is dependent on sialic acid exposure, binding of FVIII is not. Interaction of FVIII and VWF with Siglec-5 expressed at the surface of HEK293 cells leads to endocytosis of both proteins and accumulation in early endosomes. The over-expression of human Siglec-5 in mice induces the decrease in plasma levels of VWF and FVIII, suggesting that Siglec-5 contributes to the regulation of circulating levels of VWF/FVIII in human. ${ }^{52}$ Since, human MO-DCs and plasmacytoid DCs express Siglec-5, further investigations deciphering the role of this receptor in FVIII uptake and processing by human DCs would be interesting. ${ }^{53}$

\section{The macrophage mannose receptor or CD206}

To date, the only endocytic receptor that has been shown to lead to FVIII processing and presentation to $\mathrm{CD} 4 \mathrm{~T}$ cells is the macrophage mannose receptor (MMR) also known as CD206. ${ }^{54}$ Pre-incubation of MO-DCs with mannan, an antagonist of mannose-sensitive receptors, inhibits more than $50 \%$ of FVIII endocytosis, and abrogates the activation of a FVIII-specific T-cell line. ${ }^{29,55}$ CD206 is a divalent ion-dependent endocytic receptor that belongs to the C-type lectin receptor family. The tissue distribution of CD206 is well documented in mice, but remains poorly known in human. ${ }^{56}$ In human, CD206 is expressed by different macrophages and dendritic cells subsets as well as by hepatic, splenic, lymphatic and dermal microvascular endothelial cells. ${ }^{56-58}$ CD206 is involved in innate immune responses through its capacity to recognize a wide variety of pathogens (Gram-positive or Gram-negative bacteria, yeasts, parasites and mycobacteria) ${ }^{59}$ It also plays a role in adaptive immune responses and leads to antigen presentation. ${ }^{60}$ Moreover, CD206 is involved in the modulation of the catabolism of many endogenous glycoproteins in mice. ${ }^{61}$ FVIII is heavily 
glycosylated and harbors 25 potential sites of glycosylations, 20 of which are glycosylated. ${ }^{62,63}$ rFVIII and pdFVIII present similar glycosylation profiles, including high mannose structures, with bi-, tri- or tetra-antennary complex type chains, that are located on Asn239 and on Asn2118 in the A1 and C1 domain, respectively. ${ }^{62,64}$ While Asn239 carries either high-mannose, or hybrid or complex structures, Asn2118 present only high mannose structures. ${ }^{65}$ Glycans at Asn239 and at Asn2118 are implicated in FVIII binding to CD206. However, since CD206 has not been involved in FVIII endocytosis by mouse bone-marrow derived-dendritic cells, the precise role of CD206 in FVIII endocytosis and presentation to T cells in vivo remains to be demonstrated. ${ }^{49}$

\section{CLEC4M}

More recently, another C-type lectin receptor, CLEC4M, also known as CD299, L-SIGN or DC-SIGNR, was reported to bind, internalize and catabolise VWF and FVIII, either in their complex form or not. ${ }^{32,66}$ CLEC4M is expressed by sinusoïdal endothelial cells in the liver, placenta, lymph nodes, lung and gastro-intestine tractus. ${ }^{67}$ As in the case of CD206, the binding of CLEC4M is dependent on high mannose oligosaccharides exposed on FVIII. Since CLEC4M has been mostly described as an adhesion receptor, a direct role of CLEC4M in FVIII immunogenicity is unlikely.

\section{FVIII residues involved in endocytosis}

Several attempts have been made to identify the key residues of FVIII implicated in its internalization by APCs, independently from any preconceived idea on the nature of the endocytosis receptors at play. Using the monoclonal antibody KM33 that recognizes an epitope located in the $\mathrm{C} 1$ domain of FVIII, Herczenik et al have demonstrated that the Arg2090, Lys2092 and Phe2093 residues are involved in FVIII endocytosis by MO-DCs. ${ }^{31}$ 
The substitution of these residues to alanines by site directed mutagenesis generated a FVIII mutant that is significantly less internalized by APCs. ${ }^{68,69}$ More recently, using a similar approach with a monoclonal anti-C2 antibody, we demonstrated that Arg2215 and Arg2220 of the C2 domain also participate in FVIII endocytosis by MO-DCs. ${ }^{68}$ The substitution of these residues to alanine residues yielded a mutant FVIII that was less prone to endocytosis by MODCs. Mutation of the three $\mathrm{C} 1$ residues showed conflicting results on the immunogenicity of FVIII in FVIII-deficient mice. ${ }^{68,69}$ Taken together, the available data demonstrate the involvement of complex interaction networks that modulate FVIII uptake and lead either to FVIII catabolism or processing and presentation to $\mathrm{T}$ cells.

\section{Facilitation of endocytosis of FVIII by other molecules}

The experimental set-up used to study the endocytosis of FVIII by APCs generally leaves aside key proteins that may be directly or indirectly implicated in the internalization process. This is true for VWF and complement molecules which are virtually absent in serum free conditions, or are inactivated or present in low amounts when $10 \%$ decomplemented fetal calf serum is used. Our seminal work had documented a significant reduction of FVIII endocytosis by MO-DCs in the presence of VWF. ${ }^{49,70} \mathrm{VWF}$ was thus found to inhibit the binding of FVIII to CD206. ${ }^{29,55}$ Recent finding by the Voorberg lab have provided a more complexed picture of the role of VWF on FVIII endocytosis and processing by APCs. Sorvillo et al thus demonstrated that, while most of VWF remains bound to the cell membrane, FVIII-derived peptides are still detected in association with MHC class II molecules at the surface of MODCs. ${ }^{71}$ The comparison of the MHC II-bound FVIII peptidome when FVIII was incubated alone or with VWF in the presence of MO-DCs showed changes in the repertoire of FVIIIderived peptides presented on HLA-DR molecules. ${ }^{71}$ Interestingly, VWF-derived peptides were detected in association with HLA-DR molecules only when VWF was incubated with 
FVIII, suggesting that the presence of FVIII mediates VWF endocytosis. Currently, it is not clear whether the same endocytic pathways are involved when FVIII is complexed to VWF or not. Importantly, the fact that VWF was found to be endocytosed in a LRP-1-dependent manner by macrophages under shear-stress conditions, should encourage new investigations of FVIII/VWF uptake by MO-DCs under non-static conditions. The repercussion of VWF coendocytosis with FVIII on the onset of the anti-FVIII immune response in vivo is difficult to predict. It has been hypothesized that the concomitant presentation of VWF-derived peptides by APCs may recruit VWF-specific regulatory $\mathrm{T}$ cells that would down-regulate the activation of naïve FVIII-specific T cells and thus favor tolerance to therapeutic exogenous FVIII. ${ }^{72}$ This could explain at least in part the proposed protective effect played by VWF on the immunogenicity of plasma-derived FVIII. ${ }^{73}$

Molecules of the complement system play major roles in the development of innate and adaptive immune responses. Our group recently investigated the role of complement system on FVIII endocytosis and presentation to T cells by MO-DCs. We observed that the C3 component of the complement system and its cleavage product $\mathrm{C} 3 \mathrm{~b}$ increase the endocytosis of FVIII by MO-DCs and its presentation to a FVIII-specific CD4 T-cell hybridoma (Rayes et al in press). The interaction of C3b with FVIII was demonstrated by Elisa, and FVIII and C3b were found to co-localize on the surface of MO-DCs. Interestingly, complement activation restored the endocytosis of the C1 mutant (Arg2090Ala-Lys2092Ala-Phe2093Ala) by MODCs. The transient depletion of $\mathrm{C} 3$ using humanized cobra venom factor resulted in a drastic reduction of the immune response to exogenous FVIII in FVIII-deficient mice (Rayes et al in press). Taken together, these observations highlight new endocytic route(s) for FVIII which are dependent on interactions between FVIII and C3b. 


\section{Danger signals/environmental risk factors}

According to the danger signal theory proposed by Matzinger, ${ }^{74}$ the presence of danger signals in the micro-environment at the bleeding site, by promoting the maturation of APCs, is required to initiate anti-FVIII immune responses. Indeed, as explained above, naïve FVIIIspecific CD4 $\mathrm{T}$ cells can be activated only if they received signal 1 (MHC II/FVIII peptide triggering the TCR), signal 2 (co-stimulatory molecules) and signal 3 (cytokines) from APCs. Failure to provide signals 2 and 3 turns the naïve $\mathrm{T}$ cells into regulatory $\mathrm{T}$ cells. Danger signals are sensed by APCs through pattern recognition receptors (PRR). Danger signals may be of endogenous origin, such as molecules released upon cellular lesion or cellular stress, or exogenous, such as pathogen-associated molecular patterns (PAMP). Depending on the presence of such signals in the micro-environment, immune system will either initiate a neutralizing immune response or, on the contrary, will activate regulatory mechanisms. Currently, the nature of the danger signal(s) implicated in the anti-FVIII immune response remains unknown. Pfistershammer et al demonstrated that in vitro FVIII is not able to induce MO-DCs maturation. ${ }^{75}$ Accordingly, using HEK293 cell lines transfected with Toll-like receptors (TLR), a family of PRR, we reported that FVIII alone is not able to activate TLR pathway. ${ }^{76}$ More recently, Miller et al observed a synergistic effect of pdFVIII and lipopolysacharide (LPS) on the expression of the co-stimulatory molecules CD83 and CD86 on MO-DCs. It is thus possible that pdFVIII plays a synergistic role on DC maturation in the context of inflammation. ${ }^{77}$ However, the absence of an effect of rFVIII in the same experimental setup suggests that the synergistic effect of pdFVIII is induced by molecules contained in the pdFVIII product and not by the very FVIII molecule. In addition, while several clinical and pre-clinical data reported a higher risk to develop FVIII inhibitors in patients treated with rFVIII as compared to patients treated with pdFVIII, no study reported a higher risk in patients treated with pdFVIII. 
The pro-coagulant activity of FVIII may provide danger signal, since FVIII injection in a context of bleeding in HA patients activates the FX that accumulated at site of bleeding which leads to a burst of thrombin generation. ${ }^{78}$ Skupsky et al demonstrated that heat-inactivated FVIII is less immunogenic than native FVIII, and that inhibition of thrombin by hirudin at the time of FVIII administration significantly reduces the anti-FVIII immune response in FVIIIdeficient mice. ${ }^{79}$ In contrast with this finding, Meeks et al demonstrated the similar immunogenicity of wild-type FVIII and of an inactive Val634Met FVIII variant (which can be activated by thrombin but lacks co-factor activity) and an inactive Arg372Ala/Arg1689Ala FVIII variant (which cannot be cleaved by thrombin and does not dissociate from VWF). ${ }^{80}$ Furthermore, we observed that the inactive Val634Met FVIII mutant is still immunogenic in FVIII-deficient mice in the absence of activation of the extrinsic coagulation cascade pathway. ${ }^{81}$ Thus, whether the pro-coagulant activity of FVIII is a source of the danger signal that riggers the anti-FVIII immune response remains unclear.

The inflammatory state of the patients has often been proposed as a potential risk factor to develop FVIII inhibitors. FVIII injection during an infection/surgery or at the time of vaccination have been proposed to increase the risk to develop inhibitors owing to the presence of exogenous or endogenous pro-inflammatory signals.

The hypothesis was strengthened by a pilot study conducted in 26 PUPs treated by early prophylaxis, started at the time of the first bleedings and using lower frequencies and lower doses of FVIII than standard treatment (once $25 \mathrm{IU} / \mathrm{kg} /$ week versus thrice $40-50 \mathrm{IU} / \mathrm{kg} /$ week for the standard protocol). During the first 20 exposure days, FVIII injections were strictly performed at distance of possible inflammatory events such as infections, surgery or vaccinations. ${ }^{82}$ The incidence of FVIII inhibitors was significantly reduced compared to an historical control group (48\% vs 3.8\% study group). These data suggest that injection of exogenous FVIII in a context that avoids danger signals (bleeding, infection or immunization, 
etc...) decreases the risk for allo-immunization. This finding was however not reproduced in another cohort of patients, ${ }^{83}$ and studies in preclinical models of hemophilia A yielded conflicting results. While induction of an acute bleeding in the knee joint of FVIII-deficient mice did not increase the anti-FVIII immune response, ${ }^{84}$ bleeding episodes in hemophilic rats increased FVIII immunogenicity. ${ }^{85}$ As far as vaccination is concerned, a retrospective analysis on 375 PUPS on the influence of vaccination on inhibitor development, reported the absence of association between vaccination and FVIII exposure. ${ }^{86}$ Similarly, in humanized hemophilic mice, the injection of vaccinal antigens before FVIII administration decreased the frequency of immunization to exogenous FVIII. ${ }^{87}$

Several studies reported that intensive FVIII treatment in case of severe hemorrhages or surgery is associated with a higher prevalence of FVIII inhibitor development. ${ }^{88,89}$ As evoked earlier, this could be explained by alert signals inherent to these events, but also to the exposure of the organism to high amounts of FVIII antigens. Indeed, intuitively, the dose of antigen administered is predicted to affect the intensity of the induced immune response. This was demonstrated in the case of FVIII in earlier studies by Reipert et al wherein the intravenous administration of 0.1 or $1 \mu \mathrm{g}$ rFVIII to FVIII-deficient mice lead to 10 -fold different levels of anti-FVIII IgG. ${ }^{90}$

Interestingly, the use of prophylaxis in HA patients was correlated with a lower risk to develop inhibitors. ${ }^{82,88,89}$ In principle, prophylaxis, as opposed to on-demand treatment, consists in injecting lower amounts of FVIII at regular intervals independently from the occurrence of bleeding events, to provide an as continuous as possible exposure of the organism to the exogenous FVIII antigen. In line with the antigen discontinuity theory proposed by $\mathrm{T}$ Pradeu, such a continuous exposure to an exogenous antigen should prevent the onset of neutralizing immune responses and favor the induction of a peripheral tolerance..$^{91}$ 


\section{Genetic risk factors for the development of an inhibitory anti-FVIII immune response}

Among genetic risk factors, the mutation of the $F 8$ gene leading to HA has been established. Thus, mutations resulting in severe alterations of FVIII expression such as the inversion of intron 22, large deletions and nonsense mutations significantly increase the risk to develop inhibitors to therapeutic FVIII. ${ }^{92}$ Such mutations lead to the expression of a strongly truncated FVIII or to the complete absence of endogenous FVIII (intron 22 inversion) and the patients with these mutations are referred to as "cross-reactive material" (CRM) negative. From an immunological point of view, the lack of expression of endogenous FVIII in CRM-negative patients results in the absence of thymic education of newly arising $\mathrm{T}$ cells and lack of establishment of central tolerance: in absence of FVIII expression in the thymus, FVIIIreactive CD4 $\mathrm{T}$ cells are not eliminated during the process of negative selection, and FVIIIspecific regulatory $\mathrm{T}$ cells (Tregs) are not induced. In contrast, CRM-positive patients have higher chance to develop central tolerance to FVIII and hence to control the immune response to exogenous FVIII. The majority of CRM-positive patients generally produce an endogenous FVIII with a missense point mutation, that is either lacking pro-coagulant activity (e.g., FVIII with the V634M mutation), ${ }^{93}$ or that accumulates in the endoplasmic reticulum and is poorly secreted. ${ }^{94,95}$ We and others have documented the importance of the affinity for HLA-DR of the peptides from wild-type therapeutic FVIII that correspond to the peptides of endogenous FVIII that carry the HA-causing mutation, as a risk factor for allo-immunization to therapeutic FVIII. ${ }^{96-98}$ Yet, despite the fact that tolerance is not perfect when a mutated FVIII is expressed, the risk to develop FVIII inhibitors is drastically reduced in CRM-positive patients. Gouw et al in their meta-analysis on 5283 patients with severe HA from 30 different cohorts observed a higher risk in patients with large deletions or nonsense mutations as compared to patient with intron 22 inversions (INV22). ${ }^{99}$ Although somewhat surprising, those results could be explained by the intracellular expression of two FVIII polypeptides 
(FVIII $_{\text {22I }}$ et $\mathrm{FVIII}_{\mathrm{B}}$ ) in peripheral blood cells (PBMCs) and hepatic tissue from patients with INV22. ${ }^{100}$ The authors proposed that the two FVIII polypeptides may be expressed by medulary thymic epithelial cells and favor the induction of T-cell tolerance to FVIII. The latter hypothesis remains to be confirmed in view of the fact that another study failed to detect FVIII-encoding mRNA in PBMCs from INV22 patients. ${ }^{101}$ Presumable, patients who do not develop a central tolerance to FVIII, rely on the induction of peripheral tolerance in order to control of FVIII-reactive T cells.

Importantly, all CRM-negative patients do not develop inhibitors since inhibitors are detected in roughly $30 \%$ of patients with severe HA. The mechanisms involved in the induction of peripheral T-cell tolerance to FVIII CRM-negative patients and in the subsequent control of the anti-FVIII immune response have not been elucidated as yet. Investigations of the genetic risk factors associated with FVIII inhibitor development suggest the involvement of multiple factors. Polymorphisms in different immune genes, including IL-10, TNF- $\alpha$ and CTLA-4 genes, have been associated with the onset of FVIII inhibitors. ${ }^{102-104}$ In particular, polymorphisms associated with high Il-10 and TNF $\alpha$ production levels were more frequent among inhibitor-positive patients. ${ }^{105,106}$ Of note, IL-10 was first described to down-regulate the synthesis of Th1 cytokines and was associated with polarization of immune responses towards a Th2 type which are characterized by isotype switch and increased antibodymediated immune responses. Hu et al reported that proliferating FVIII-specific CD4 T cells exhibit different phenotypes depending on the immune status of the patients. While T-cell blasts generated from inhibitor-positive patients were polarized towards both the Th2 (positive for the interleukin Il-4) and Th1 (positive for the cytokine IFN- $\gamma$ ) pathways, T-cell blasts obtained from inhibitor-negative patients were of Th1 and Th3 (TGF- $\beta$-positive) type. Interestingly, FVIII-specific T cell blasts isolated from healthy donors were polarized either towards the Th1 or Th3 pathways, but never towards Th2. ${ }^{107}$ The authors proposed that Th1 
cells may mostly be implicated in the initiation of anti-FVIII immune response, whereas polarization towards a Th2 response may favor the development of a strong immune response to FVIII with the production of FVIII inhibitors. However, the underlying mechanisms are probably more complex since Il-10, a typical Th2-type cytokine that is also the hallmark of Tregs, is produced by monocytes and is endowed with pleiotropic effects in immunoregulation and inflammation. For example, IL-10 down-regulates the expression of MHC class II and costimulatory molecules at the surface of macrophages, while promoting Bcell survival and proliferation. The $\mathrm{ABO}$ blood groups were recently proposed to modulate FVIII immunogenicity. Thus, Franchini et al reported in a retrospective study on a small cohort of severe hemophilia A that non-O blood group patients have a higher risk to develop inhibitors, independently from other covariates (FVIII products, $F 8$ mutation). ${ }^{108}$ To date, ABO blood groups have mostly been reported to influence VWF and FVIII clearance. ${ }^{109}$ The mechanisms underlying the reduced immunogenicity of FVIII in blood group O patients remain to be determined. Recent investigations involving the genome-wide association of 13,331 single nucleotides polymorphisms (SNPs) from 1,081 immune genes in 833 patients with severe $\mathrm{HA}^{110}$ have revealed additional polymorphisms in multiple genes involved in immune regulation. Thirteen SNPs were significantly associated with inhibitor risk, 5 SNPs being correlated with an increase prevalence (MAPK9, DOCK2, CD44, IQGAP2 and CSF1R), and 8 SNPs being apparently protective (PDGFRB, PCGF2, HSP90B1, F13A1, IGSF2, ALOX5AP, MAP2K4 and PTPRN2).

Of note, we have reported the increased prevalence of short tandem GT repeats in the promoter of the gene encoding heme-oxygenase 1 (HO-1) in patients who have developed inhibitory antibodies to FVIII. ${ }^{111} \mathrm{HO}-1$ catalyses heme to generate the anti-inflammatory and immuno-suppressive compounds carbon monoxide and biliverdin, and has been associated with Treg functions. ${ }^{112,113}$ Recently, another regulatory enzyme that also supports Treg 
functions was implicated in the control of the anti-FVIII immune response: indoleamine 2,3dioxygenase 1 (IDO1). ${ }^{114}$ IDO1 is a heme-enzyme involved in the metabolism of tryptophan and is expressed by various cell types including DCs. Tryptophan metabolites resulting from IDO1 activity promote immune tolerance by inducing the apoptosis of $\mathrm{T}$ cells and promoting the differentiation of Tregs. ${ }^{115}$ Interestingly, PBMCs isolated from inhibitor-positive HA patients failed to express IDO1 and anti-inflammatory cytokines upon in vitro TLR9 stimulation in contrast to PBMCs from inhibitor-negative patients. Interestingly, in FVIIIdeficient mice, the induction of HMOX-1 and of IDO1 were independently found to protect from the development of a humoral response to FVIII. ${ }^{114,116}$ Taken together, these observations suggest the existence of mechanisms of peripheral induction of T-cell tolerance to FVIII that are deficient in patients with FVIII inhibitors.

\section{Therapeutic strategies to prevent and control the anti-FVIII immune response}

\section{Modification of FVIII structure}

The endocytosis of FVIII being a prerequisite for the onset of the anti-FVIII immune response, a strategy consists in modifying the structure of FVIII in order to prevent its recognition by APCs. The modification of residues involved in FVIII endocytosis by DCs at the level of the $\mathrm{C} 1$ or $\mathrm{C} 2$ domains as well as Asn2118 was shown to prevent the uptake of FVIII by human DCs but did not abrogate the onset of the anti-FVIII immune response in FVIII-deficient mice. ${ }^{68,117}$ Moreover, designing less immunogenic FVIII molecules by introducing mutations may be hardly compatible with the preservation of its structure and procoagulant activity. An alternative to the traditional approach of site directed mutagenesis has recently been explored to generate better expressed and possibly less immunogenic FVIII variants. Using ancestral sequence reconstruction (ASR), Zakas et al have recently identified two common FVIII-encoding ancestor genes: An53 from the rodent lineage and An68 from a 
lineage common to primates and rodents, that share 95 and $87 \%$ homology with human FVIII sequence, respectively. ${ }^{118}$ Recombinant BDD An53 and An68 were more efficiently produced and secreted than human BDD-FVIII. Interestingly, the two ancestor FVIII molecules were also less antigenic than BDD-FVIII as they were poorly recognized and neutralized by a panel of anti-A2 and anti-C2 monoclonal antibodies. Further investigations on T-cell epitope prediction as well as immunogenicity in preclinical models of HA are needed to determine whether ASR is a viable strategy to design less immunogenic FVIII in the future.

\section{Immuno-intervention}

Prevention of HLA-DR mediated interactions between APCs and T cells

A strategy to prevent the initiation of the anti-FVIII immune response consists in preventing the signalization required for the priming of naive FVIII-specific T cells by targeting signal 1 (Table 2). Using in silico measurement of the binding of FVIII-derived peptide to MHC II molecules, Moise et al predicted key modifications of major immuno-dominant T-cell epitopes at the level of the $\mathrm{C} 2$ domain. The substitutions drastically decreased the affinity of FVIII peptides affinity for MHC II as well as subsequently T-cell activation. ${ }^{119}$ Although theoretically attractive, such a 'de-immunization' strategy of FVIII appears risky and highly complex in view of the polyclonality of the anti-FVIII immune response and involvement of a large number of T-cell epitopes largely spread over the FVIII structure, and in view of the complexity of introducing point mutations in FVIII without affecting its pro-coagulant activity and ability of being intracellularly trafficked and secreted, as evoked earlier. ${ }^{120}$

Inhibition of B cells 
B cells are the precursors of plasma cells that secrete anti-FVIII antibodies. Several strategies for targeting $\mathrm{B}$ cells have been tested, including the use of proteasome inhibitors. ${ }^{17}$ One promising strategy is based on the use of liposomal nanoparticles coated with FVIII and the CD22 ligand (CD22L). ${ }^{121}$ Stimulation of the BCR in association with CD22 signalization down regulates $\mathrm{B}$ cells in an antigen-specific manner. ${ }^{122}$ Indeed, in FVIII-deficient mice, a single administration of FVIII and CD22L complexed to liposomes nanoparticles reduced the production of inhibitory anti-FVIII IgG. However, the latter strategy has not been tested in the context of repeated injections of FVIII which would be necessary to evaluate the induction of tolerance to FVIII. Our yet unpublished work demonstrates that blocking the BCR signalization pathway using inhibitors of the Bruton's tyrosine kinase does not prevent the onset of a naive anti-FVIII immune response in mice, but reduces the memory response to therapeutic FVIII in FVIII-challenged mice, thus paving the way to strategies aimed at ameliorating the outcome of immune tolerance induction by administration of high dose FVIII.

\section{Induction of T-cell tolerance}

Drug-mediated immunosuppression has been tested with success in preclinical models of HA. Thus, the daily per os administration to FVIII-deficient mice of rapamycin, an inhibitor of the Il-2 signalization pathway, concomitantly with repeated injections of FVIII was associated with a significant decrease in the anti-FVIII humoral response. ${ }^{123}$ Rapamycin treatment favored the emergence of CD4+CD25+Foxp3+ regulatory $\mathrm{T}$ cells and down-regulated $\mathrm{Th} 2$ polarization. Rapamycin-mediated immunosuppression was however not antigen-specific. Recent investigations using synthetic nanoparticles containing rapamycin and FVIII gave promising results in hemophilic mice. ${ }^{124} \mathrm{~A}$ very brief low dose regimen of methotrexate has 
been recently shown to promote tolerance to the human therapeutic enzyme alglucosidase alfa in a mouse model of Pompe disease. Methotrexate-induced tolerance involved the induction of regulatory B cells that secrete Il-10 and TGF- $\beta .{ }^{125}$ The effect of methotrexate in dampening FVIII immunogenicity remains to be tested.

Another alternative approach to favor the expansion of Tregs in vivo consists in the use of IL2/anti-IL-2 antibody (JES6-1) complexes. ${ }^{126}$ The administration of this complex in parallel to FVIII treatment during 4 weeks was found to inhibit the production of anti-FVIII antibodies in mice, and to induce tolerance in the following weeks. The protective effect was associated with a 7-fold increase in the number of circulating natural CD4+CD25+Foxp3+Helios Tregs, as compared to a control group. The Tregs were however short-lived, highly suppressive but probably not specific for FVIII. In parallel, FVIII-specific human regulatory $\mathrm{T}$ cells engineered by retroviral transduction of polyclonal Tregs from healthy donors with an antiFVIII TCR coding sequence was shown to down-regulate anti-FVIII T and B cell responses in vitro. ${ }^{127}$ In a different strategy, our group has shown that the injection to pregnant FVIIIdeficient mice with the $\mathrm{A} 2$ and $\mathrm{C} 2$ domains of FVIII fused to the murin Fc $\gamma 1$ fragment, is followed by the transplacental transfer of $\mathrm{A} 2-\mathrm{Fc} \gamma 1$ and $\mathrm{C} 2-\mathrm{Fc} \gamma 1$ to the foetuses. The transfer was dependent on the neonatal Fc receptor and induced central as well as peripheral T-cell tolerance that lasted for several weeks after birth. ${ }^{128}$

Lastly, the induction of FVIII-specific tolerance upon administration of FVIII by the oral route has been investigated. The latter strategy exploits the tolerogenic environment that characterizes the gut-associated lymphoid tissue. The proof of concept was brought with the oral administration of the purified C2 domain of FVIII to FVIII-deficient mice, either by the nasal or oral routes, prior to subcutaneous injection of the $\mathrm{C} 2$ domain with adjuvant. ${ }^{129}$ However, induction of tolerance using this protocol requires enormous quantities of FVIII and the maintenance of FVIII integrity until it reaches the gut. In an alternative attempt, bio- 
encapsulated FVIII fragments fused to the B subunit of the cholera toxin (CTB), a transmucosal carrier, allowed the absorption of FVIII fragments by gut microbial flora follow gavage. The treated mice demonstrated a drastically reduced humoral anti-FVIII response. ${ }^{130}$

\section{Conclusion}

The present days are facing a paradoxical situation where a myriad of different approaches for immuno-intervention and induction of specific tolerance to FVIII are being validated in hemophilic mice, and where novel therapies using bypassing agents or gene therapy may render the administration of exogenous FVIII no longer the standard of care in the future. At the same time, the knowledge we have of the elevated immunogenicity of FVIII in HA patients remains very incomplete and fragmented. Advances in our understanding of the way FVIII is captured and internalized by APCs, of the nature of the dominant T and B cell epitopes, of the major genetic risk factors as well as in the validation or refutation of intuitively proposed danger signals are however undeniable. From both a scientific and clinical points of views, we strongly believe that deciphering the immunogenicity of FVIII should remain a priority for the community. Importantly, the experience accumulated in the field of FVIII and hemophilia A shall lead the way in the more general context of immunogenicity of therapeutic proteins.

\section{Acknowledgements}

This work was supported by Institut National de la Santé et de la Recherche Médicale (INSERM), Centre National de la Recherche Scientifique (CNRS), and Université Pierre et Marie Curie (UPMC) Paris 6. Jules Russick is the recipient of a fellowship from Ministère de l'enseignement supérieur et de la recherche (France). The research leading to this work was conducted as part of the ABIRISK consortium (Anti-Biopharmaceutical Immunization: 
prediction and analysis of clinical relevance to minimize the risk). For further information please refer to www.abirisk.eu. 


\section{References}

1. Dasgupta S, Bayry J, André S, Dimitrov JD, Kaveri SV, Lacroix-Desmazes S. Auditing Protein Therapeutics Management by Professional APCs: Toward Prevention of Immune Responses against Therapeutic Proteins. J Immunol. 2008;181(3):1609-1615. doi:10.4049/jimmunol.181.3.1609

2. Pineda C, Castañeda Hernández G, Jacobs IA, Alvarez DF, Carini C. Assessing the Immunogenicity of Biopharmaceuticals. Biodrugs. 2016;30:195-206. doi:10.1007/s40259-016-0174-5

3. Lacroix-Desmazes S, Navarrete A-M, André S, Bayry J, Kaveri SV, Dasgupta S. Dynamics of factor VIII interactions determine its immunologic fate in hemophilia A. Blood. 2008;112(2):240-249. doi:10.1182/blood-2008-02-124941

4. Bray GL, Kroner BL, Arkin S, et al. Loss of high-responder inhibitors in patients with severe hemophilia $A$ and human immunodeficiency virus type 1 infection: a report from the MultiCenter Hemophilia Cohort Study. Am J Hematol. 1993;42(4):375-379.

5. Qian J, Burkly LC, Smith EP, et al. Role of CD154 in the secondary immune response: the reduction of pre-existing splenic germinal centers and anti-factor VIII inhibitor titer. Eur $J$ Immunol. 2000;30(9):2548-2554. doi:10.1002/1521-4141(200009)30:9<2548::AIDIMMU2548>3.0.CO;2-H

6. Reipert BM, Sasgary M, Ahmad RU, Auer W, Turecek PL, Schwarz HP. Blockade of CD40/CD40 ligand interactions prevents induction of factor VIII inhibitors in hemophilic mice but does not induce lasting immune tolerance. Thromb Haemost. 2001;86(6):1345-1352.

7. Rossi G, Sarkar J, Scandella D. Long-term induction of immune tolerance after blockade of CD40CD40L interaction in a mouse model of hemophilia A. Blood. 2001;97(9):2750-2757.

8. Qian J, Collins M, Sharpe AH, Hoyer LW. Prevention and treatment of factor VIII inhibitors in murine hemophilia A. Blood. 2000;95(4):1324-1329.

9. Nutt SL, Hodgkin PD, Tarlinton DM, Corcoran LM. The generation of antibody-secreting plasma cells. Nat Rev Immunol. 2015;15(3):160-171. doi:10.1038/nri3795

10. Kurosaki T, Kometani K, Ise W. Memory B cells. Nat Rev Immunol. 2015;15(3):149-159. doi:10.1038/nri3802

11. Kometani K, Nakagawa R, Shinnakasu R, et al. Repression of the transcription factor Bach2 contributes to predisposition of IgG1 memory B cells toward plasma cell differentiation. Immunity. 2013;39(1):136-147. doi:10.1016/j.immuni.2013.06.011

12. Moser K, Tokoyoda K, Radbruch A, MacLennan I, Manz RA. Stromal niches, plasma cell differentiation and survival. Curr Opin Immunol. 2006;18(3):265-270. doi:10.1016/j.coi.2006.03.004

13. Hofbauer CJ, Whelan SFJ, Hirschler M, et al. Affinity of FVIII-specific antibodies reveals major differences between neutralizing and nonneutralizing antibodies in humans. Blood. 2015;125(7):1180-1188. doi:10.1182/blood-2014-09-598268

14. Reipert BM. B-cell memory against factor VIII. Cell Immunol. 2016;301:49-58. doi:10.1016/j.cellimm.2016.01.003 
15. Whelan SFJ, Hofbauer CJ, Horling FM, et al. Distinct characteristics of antibody responses against factor VIII in healthy individuals and in different cohorts of hemophilia A patients. Blood. 2013;121(6):1039-1048. doi:10.1182/blood-2012-07-444877

16. van Helden PMW, Kaijen PHP, Fijnvandraat K, van den Berg HM, Voorberg J. Factor VIII-specific memory B cells in patients with hemophilia A. J Thromb Haemost JTH. 2007;5(11):2306-2308. doi:10.1111/j.1538-7836.2007.02736.x

17. Meslier $Y$, André S, Dimitrov JD, et al. Bortezomib delays the onset of factor VIII inhibitors in experimental hemophilia A, but fails to eliminate established anti-factor VIII IgG-producing cells. J Thromb Haemost JTH. 2011;9(4):719-728. doi:10.1111/j.1538-7836.2011.04200.x

18. Hausl C, Maier E, Schwarz HP, et al. Long-term persistence of anti-factor VIII antibody-secreting cells in hemophilic mice after treatment with human factor VIII. Thromb Haemost. 2002;87(5):840-845.

19. Zerra PE, Cox C, Baldwin WH, et al. Marginal zone B cells are critical to factor VIII inhibitor formation in mice with hemophilia A. Blood. October 2017. doi:10.1182/blood-2017-05-782912

20. Arnon TI, Horton RM, Grigorova IL, Cyster JG. Visualization of splenic marginal zone B-cell shuttling and follicular B-cell egress. Nature. 2013;493(7434):684-688. doi:10.1038/nature11738

21. Archambault AS, Carrero JA, Barnett LG, et al. Cutting edge: Conditional MHC class II expression reveals a limited role for B cell antigen presentation in primary and secondary CD4 T cell responses. J Immunol Baltim Md 1950. 2013;191(2):545-550. doi:10.4049/jimmunol.1201598

22. den Haan JMM, Kraal G. Innate immune functions of macrophage subpopulations in the spleen. $J$ Innate Immun. 2012;4(5-6):437-445. doi:10.1159/000335216

23. Navarrete A, Dasgupta $S$, Delignat $S$, et al. Splenic marginal zone antigen-presenting cells are critical for the primary allo-immune response to therapeutic factor VIII in hemophilia A. J Thromb Haemost JTH. 2009;7(11):1816-1823. doi:10.1111/j.1538-7836.2009.03571.x

24. Borges da Silva $H$, Fonseca R, Pereira RM, Cassado ADA, Álvarez JM, D'Império Lima MR. Splenic Macrophage Subsets and Their Function during Blood-Borne Infections. Front Immunol. 2015;6:480. doi:10.3389/fimmu.2015.00480

25. Delamarre L, Pack M, Chang H, Mellman I, Trombetta ES. Differential lysosomal proteolysis in antigen-presenting cells determines antigen fate. Science. 2005;307(5715):1630-1634. doi:10.1126/science.1108003

26. Trombetta ES, Mellman I. Cell biology of antigen processing in vitro and in vivo. Annu Rev Immunol. 2005;23:975-1028. doi:10.1146/annurev.immunol.22.012703.104538

27. Mebius RE, Kraal G. Structure and function of the spleen. Nat Rev Immunol. 2005;5(8):606-616. doi:10.1038/nri1669

28. Banchereau J, Steinman RM. Dendritic cells and the control of immunity. Nature. 1998;392(6673):245-252. doi:10.1038/32588

29. Dasgupta S, Navarrete A-M, Bayry J, et al. A role for exposed mannosylations in presentation of human therapeutic self-proteins to CD4+ T lymphocytes. Proc Natl Acad Sci U S A. 2007;104(21):8965-8970. doi:10.1073/pnas.0702120104 
30. van Haren SD, Herczenik E, ten Brinke A, Mertens K, Voorberg J, Meijer AB. HLA-DR-presented peptide repertoires derived from human monocyte-derived dendritic cells pulsed with blood coagulation factor VIII. Mol Cell Proteomics MCP. 2011;10(6):M110.002246. doi:10.1074/mcp.M110.002246

31. Herczenik E, van Haren SD, Wroblewska A, et al. Uptake of blood coagulation factor VIII by dendritic cells is mediated via its C1 domain. J Allergy Clin Immunol. 2012;129(2):501-509, 509.e1-5. doi:10.1016/j.jaci.2011.08.029

32. Lai JD, Georgescu MT, Hough C, Lillicrap D. To clear or to fear: An innate perspective on factor VIII immunity. Cell Immunol. 2016;301:82-89. doi:10.1016/j.cellimm.2015.10.011

33. Lenting PJ, Christophe OD, Guéguen P. The disappearing act of factor VIII. Haemoph Off J World Fed Hemoph. 2010;16(102):6-15. doi:10.1111/j.1365-2516.2008.01864.x

34. Lenting PJ, Neels JG, van den Berg BM, et al. The light chain of factor VIII comprises a binding site for low density lipoprotein receptor-related protein. J Biol Chem. 1999;274(34):2373423739.

35. Saenko EL, Yakhyaev AV, Mikhailenko I, Strickland DK, Sarafanov AG. Role of the low density lipoprotein-related protein receptor in mediation of factor VIII catabolism. I Biol Chem. 1999;274(53):37685-37692.

36. Bovenschen N, Herz J, Grimbergen JM, et al. Elevated plasma factor VIII in a mouse model of low-density lipoprotein receptor-related protein deficiency. Blood. 2003;101(10):3933-3939. doi:10.1182/blood-2002-07-2081

37. Vormittag $\mathrm{R}$, Bencur $\mathrm{P}$, Ay $\mathrm{C}$, et al. Low-density lipoprotein receptor-related protein 1 polymorphism $663 \mathrm{C}>\mathrm{T}$ affects clotting factor VIII activity and increases the risk of venous thromboembolism. J Thromb Haemost JTH. 2007;5(3):497-502. doi:10.1111/j.15387836.2006.02337.x

38. Bovenschen N, Boertjes RC, van Stempvoort G, et al. Low density lipoprotein receptor-related protein and factor IXa share structural requirements for binding to the A3 domain of coagulation factor VIII. J Biol Chem. 2003;278(11):9370-9377. doi:10.1074/jbc.M212053200

39. Sarafanov AG, Makogonenko EM, Pechik IV, et al. Identification of coagulation factor VIII A2 domain residues forming the binding epitope for low-density lipoprotein receptor-related protein. Biochemistry (Mosc). 2006;45(6):1829-1840. doi:10.1021/bi0520380

40. Bovenschen N, van Stempvoort G, Voorberg J, Mertens K, Meijer AB. Proteolytic cleavage of factor VIII heavy chain is required to expose the binding-site for low-density lipoprotein receptor-related protein within the A2 domain. J Thromb Haemost JTH. 2006;4(7):1487-1493. doi:10.1111/j.1538-7836.2006.01965.x

41. Sarafanov AG, Ananyeva NM, Shima M, Saenko EL. Cell surface heparan sulfate proteoglycans participate in factor VIII catabolism mediated by low density lipoprotein receptor-related protein. J Biol Chem. 2001;276(15):11970-11979. doi:10.1074/jbc.M008046200

42. Rastegarlari G, Pegon JN, Casari C, et al. Macrophage LRP1 contributes to the clearance of von Willebrand factor. Blood. 2012;119(9):2126-2134. doi:10.1182/blood-2011-08-373605

43. Pawaria S, Binder RJ. CD91-dependent programming of T-helper cell responses following heat shock protein immunization. Nat Commun. 2011;2:521. doi:10.1038/ncomms1524 
44. Pawaria S, Messmer MN, Zhou YJ, Binder RJ. A role for the heat shock protein-CD91 axis in the initiation of immune responses to tumors. Immunol Res. 2011;50(2-3):255-260. doi:10.1007/s12026-011-8221-2

45. Redzovic A, Gulic T, Laskarin G, Eminovic S, Haller H, Rukavina D. Heat-Shock Proteins 70 Induce Pro-Inflammatory Maturation Program in Decidual CD1a(+) Dendritic Cells. Am J Reprod Immunol N Y N 1989. 2015;74(1):38-53. doi:10.1111/aji.12374

46. van den Biggelaar M, Madsen JJ, Faber JH, et al. Factor VIII Interacts with the Endocytic Receptor Low-density Lipoprotein Receptor-related Protein 1 via an Extended Surface Comprising "HotSpot" Lysine Residues. J Biol Chem. 2015;290(27):16463-16476. doi:10.1074/jbc.M115.650911

47. Bovenschen N, Mertens K, Hu L, Havekes LM, van Vlijmen BJM. LDL receptor cooperates with LDL receptor-related protein in regulating plasma levels of coagulation factor VIII in vivo. Blood. 2005;106(3):906-912. doi:10.1182/blood-2004-11-4230

48. Dasgupta S, Navarrete AM, André S, et al. Factor VIII bypasses CD91/LRP for endocytosis by dendritic cells leading to T-cell activation. Haematologica. 2008;93(1):83-89. doi:10.3324/haematol.11535

49. Delignat $S$, Repessé $Y$, Navarrete A-M, et al. Immunoprotective effect of von Willebrand factor towards therapeutic factor VIII in experimental haemophilia A. Haemoph Off J World Fed Hemoph. 2012;18(2):248-254. doi:10.1111/j.1365-2516.2011.02679.x

50. Bovenschen N, Rijken DC, Havekes LM, van Vlijmen BJM, Mertens K. The B domain of coagulation factor VIII interacts with the asialoglycoprotein receptor. J Thromb Haemost JTH. 2005;3(6):1257-1265. doi:10.1111/j.1538-7836.2005.01389.x

51. Fijnvandraat K, Berntorp E, ten Cate JW, et al. Recombinant, B-domain deleted factor VIII ( $r$-VIII SQ): pharmacokinetics and initial safety aspects in hemophilia A patients. Thromb Haemost. 1997;77(2):298-302.

52. Pegon JN, Kurdi M, Casari C, et al. Factor VIII and von Willebrand factor are ligands for the carbohydrate-receptor Siglec-5. Haematologica. 2012;97(12):1855-1863. doi:10.3324/haematol.2012.063297

53. Lock K, Zhang J, Lu J, Lee SH, Crocker PR. Expression of CD33-related siglecs on human mononuclear phagocytes, monocyte-derived dendritic cells and plasmacytoid dendritic cells. Immunobiology. 2004;209(1-2):199-207. doi:10.1016/j.imbio.2004.04.007

54. Navarrete A-M, Dasgupta S, Teyssandier M, et al. Endocytic receptor for pro-coagulant factor VIII: relevance to inhibitor formation. Thromb Haemost. 2010;104(6):1093-1098. doi:10.1160/TH10-05-0294

55. Repessé $\mathrm{Y}$, Dasgupta S, Navarrete A-M, Delignat S, Kaveri SV, Lacroix-Desmazes S. Mannosesensitive receptors mediate the uptake of factor VIII therapeutics by human dendritic cells. $J$ Allergy Clin Immunol. 2012;129(4):1172-1173; author reply 1174-1175. doi:10.1016/j.jaci.2012.01.048

56. Martinez-Pomares L. The mannose receptor. J Leukoc Biol. 2012;92(6):1177-1186. doi:10.1189/jlb.0512231 
57. Gröger $M$, Holnthoner W, Maurer $D$, et al. Dermal microvascular endothelial cells express the 180-kDa macrophage mannose receptor in situ and in vitro. J Immunol Baltim Md 1950. 2000;165(10):5428-5434.

58. Pontow SE, Kery V, StahI PD. Mannose receptor. Int Rev Cytol. 1992;137B:221-244.

59. Stahl PD, Ezekowitz RA. The mannose receptor is a pattern recognition receptor involved in host defense. Curr Opin Immunol. 1998;10(1):50-55.

60. Taylor PR, Martinez-Pomares L, Stacey M, Lin H-H, Brown GD, Gordon S. Macrophage receptors and immune recognition. Annu Rev Immunol. 2005;23:901-944. doi:10.1146/annurev.immunol.23.021704.115816

61. Lee SJ, Evers S, Roeder D, et al. Mannose receptor-mediated regulation of serum glycoprotein homeostasis. Science. 2002;295(5561):1898-1901. doi:10.1126/science.1069540

62. Medzihradszky KF, Besman MJ, Burlingame AL. Structural characterization of site-specific Nglycosylation of recombinant human factor VIII by reversed-phase high-performance liquid chromatography-electrospray ionization mass spectrometry. Anal Chem. 1997;69(19):39863994.

63. Vehar GA, Keyt B, Eaton D, et al. Structure of human factor VIII. Nature. 1984;312(5992):337342.

64. Hironaka T, Furukawa K, Esmon PC, et al. Comparative study of the sugar chains of factor VIII purified from human plasma and from the culture media of recombinant baby hamster kidney cells. J Biol Chem. 1992;267(12):8012-8020.

65. Kannicht C, Ramström M, Kohla G, et al. Characterisation of the post-translational modifications of a novel, human cell line-derived recombinant human factor VIII. Thromb Res. 2013;131(1):7888. doi:10.1016/j.thromres.2012.09.011

66. Rydz N, Swystun LL, Notley C, et al. The C-type lectin receptor CLEC4M binds, internalizes, and clears von Willebrand factor and contributes to the variation in plasma von Willebrand factor levels. Blood. 2013;121(26):5228-5237. doi:10.1182/blood-2012-10-457507

67. Zhang F, Ren S, Zuo Y. DC-SIGN, DC-SIGNR and LSECtin: C-type lectins for infection. Int Rev Immunol. 2014;33(1):54-66. doi:10.3109/08830185.2013.834897

68. Gangadharan $\mathrm{B}$, Ing $\mathrm{M}$, Delignat $\mathrm{S}$, et al. The $\mathrm{C} 1$ and $\mathrm{C} 2$ domains of blood coagulation factor VIII mediate its endocytosis by dendritic cells. Haematologica. October 2016. doi:10.3324/haematol.2016.148502

69. Wroblewska A, van Haren SD, Herczenik E, et al. Modification of an exposed loop in the C1 domain reduces immune responses to factor VIII in hemophilia A mice. Blood. 2012;119(22):5294-5300. doi:10.1182/blood-2011-11-391680

70. Dasgupta S, Repessé $Y$, Bayry J, et al. VWF protects FVIII from endocytosis by dendritic cells and subsequent presentation to immune effectors. Blood. 2007;109(2):610-612. doi:10.1182/blood2006-05-022756

71. Sorvillo N, Hartholt RB, Bloem E, et al. von Willebrand factor binds to the surface of dendritic cells and modulates peptide presentation of factor VIII. Haematologica. 2016;101(3):309-318. doi:10.3324/haematol.2015.137067 
72. Lai J, Hough C, Tarrant J, Lillicrap D. Biological considerations of plasma-derived and recombinant factor VIII immunogenicity. Blood. 2017;129(24):3147-3154. doi:10.1182/blood2016-11-750885

73. Peyvandi F, Mannucci PM, Garagiola I, et al. A Randomized Trial of Factor VIII and Neutralizing Antibodies in Hemophilia A. N Engl J Med. 2016;374(21):2054-2064. doi:10.1056/NEJMoa1516437

74. Matzinger P. The danger model: a renewed sense of self. Science. 2002;296(5566):301-305. doi:10.1126/science.1071059

75. Pfistershammer K, Stöckl J, Siekmann J, Turecek PL, Schwarz HP, Reipert BM. Recombinant factor VIII and factor VIII-von Willebrand factor complex do not present danger signals for human dendritic cells. Thromb Haemost. 2006;96(3):309-316. doi:10.1160/TH05-11-0729

76. Teyssandier M, André S, Gupta N, et al. Therapeutic factor VIII does not trigger TLR1.2 and TLR2.6 signalling in vitro. Haemoph Off J World Fed Hemoph. 2013;19(3):399-402. doi:10.1111/hae.12081

77. Miller L, Weissmüller S, Ringler E, et al. Danger signal-dependent activation of human dendritic cells by plasma-derived factor VIII products. Thromb Haemost. 2015;114(2):268-276. doi:10.1160/TH14-09-0789

78. Dargaud $\mathrm{Y}$, Béguin $\mathrm{S}$, Lienhart $\mathrm{A}$, et al. Evaluation of thrombin generating capacity in plasma from patients with haemophilia A and B. Thromb Haemost. 2005;93(3):475-480. doi:10.1160/TH04-10-0706

79. Skupsky J, Zhang A-H, Su Y, Scott DW. A role for thrombin in the initiation of the immune response to therapeutic factor VIII. Blood. 2009;114(21):4741-4748. doi:10.1182/blood-2008-10186452

80. Meeks SL, Cox CL, Healey JF, et al. A major determinant of the immunogenicity of factor VIII in a murine model is independent of its procoagulant function. Blood. 2012;120(12):2512-2520. doi:10.1182/blood-2012-02-412361

81. Gangadharan B, Delignat S, Ollivier $V$, et al. Role of coagulation-associated processes on factor VIII immunogenicity in a mouse model of severe hemophilia A. J Thromb Haemost JTH. 2014;12(12):2065-2069. doi:10.1111/jth.12740

82. Kurnik K, Bidlingmaier C, Engl W, Chehadeh H, Reipert B, Auerswald G. New early prophylaxis regimen that avoids immunological danger signals can reduce FVIII inhibitor development. Haemoph Off J World Fed Hemoph. 2010;16(2):256-262. doi:10.1111/j.1365-2516.2009.02122.x

83. Auerswald G, Kurnik K, Aledort LM, et al. The EPIC study: a lesson to learn. Haemoph Off J World Fed Hemoph. 2015;21(5):622-628. doi:10.1111/hae.12666

84. Peyron I, Dimitrov JD, Delignat S, et al. Haemarthrosis and arthropathy do not favour the development of factor VIII inhibitors in severe haemophilia A mice. Haemoph Off J World Fed Hemoph. 2015;21(1):e94-98. doi:10.1111/hae.12579

85. Lövgren KM, Søndergaard H, Skov S, Wiinberg B. Joint bleeds increase the inhibitor response to human factor VIII in a rat model of severe haemophilia A. Haemoph Off J World Fed Hemoph. 2016;22(5):772-779. doi:10.1111/hae.13014 
86. Platokouki H, Fischer K, Gouw SC, et al. Vaccinations are not associated with inhibitor development in boys with severe haemophilia A. Haemoph Off J World Fed Hemoph. December 2017. doi:10.1111/hae.13387

87. Lai JD, Moorehead PC, Sponagle K, et al. Concurrent influenza vaccination reduces anti-FVIII antibody responses in murine hemophilia A. Blood. 2016;127(26):3439-3449. doi:10.1182/blood-2015-11-679282

88. Gouw SC, van den Berg HM, le Cessie S, van der Bom JG. Treatment characteristics and the risk of inhibitor development: a multicenter cohort study among previously untreated patients with severe hemophilia A. J Thromb Haemost JTH. 2007;5(7):1383-1390. doi:10.1111/j.15387836.2007.02595.x

89. Gouw SC, van den Berg HM, Fischer K, et al. Intensity of factor VIII treatment and inhibitor development in children with severe hemophilia A: the RODIN study. Blood. 2013;121(20):40464055. doi:10.1182/blood-2012-09-457036

90. Reipert BM, Ahmad RU, Turecek PL, Schwarz HP. Characterization of antibodies induced by human factor VIII in a murine knockout model of hemophilia A. Thromb Haemost. 2000;84(5):826-832.

91. Pradeu $\mathrm{T}$, Jaeger $\mathrm{S}$, Vivier $\mathrm{E}$. The speed of change: towards a discontinuity theory of immunity? Nat Rev Immunol. 2013;13(10):764-769. doi:10.1038/nri3521

92. Goodeve AC, Peake IR. The molecular basis of hemophilia A: genotype-phenotype relationships and inhibitor development. Semin Thromb Hemost. 2003;29(1):23-30. doi:10.1055/s-200337936

93. Amano K, Sarkar R, Pemberton S, Kemball-Cook G, Kazazian HH, Kaufman RJ. The molecular basis for cross-reacting material-positive hemophilia $A$ due to missense mutations within the A2domain of factor VIII. Blood. 1998;91(2):538-548.

94. David D, Saenko EL, Santos IM, et al. Stable recombinant expression and characterization of the two haemophilic factor VIII variants C329S (CRM(-)) and G1948D (CRM(r)). Br J Haematol. 2001;113(3):604-615.

95. Pipe SW, Kaufman RJ. Factor VIII C2 domain missense mutations exhibit defective trafficking of biologically functional proteins. J Biol Chem. 1996;271(41):25671-25676.

96. Pashov AD, Calvez T, Gilardin L, et al. In silico calculated affinity of FVIII-derived peptides for HLA class II alleles predicts inhibitor development in haemophilia A patients with missense mutations in the F8 gene. Haemoph Off J World Fed Hemoph. 2014;20(2):176-184. doi:10.1111/hae.12276

97. Shepherd AJ, Skelton S, Sansom CE, Gomez K, Moss DS, Hart DP. A large-scale computational study of inhibitor risk in non-severe haemophilia A. Br J Haematol. 2015;168(3):413-420. doi:10.1111/bjh.13131

98. Yanover C, Jain N, Pierce G, Howard TE, Sauna ZE. Pharmacogenetics and the immunogenicity of protein therapeutics. Nat Biotechnol. 2011;29(10):870-873. doi:10.1038/nbt.2002

99. Gouw SC, van den Berg HM, Oldenburg J, et al. F8 gene mutation type and inhibitor development in patients with severe hemophilia A: systematic review and meta-analysis. Blood. 2012;119(12):2922-2934. doi:10.1182/blood-2011-09-379453 
100. Pandey GS, Yanover C, Miller-Jenkins LM, et al. Endogenous factor VIII synthesis from the intron 22-inverted F8 locus may modulate the immunogenicity of replacement therapy for hemophilia A. Nat Med. 2013;19(10):1318-1324. doi:10.1038/nm.3270

101. Everett LA, Cleuren ACA, Khoriaty RN, Ginsburg D. Murine coagulation factor VIII is synthesized in endothelial cells. Blood. 2014;123(24):3697-3705. doi:10.1182/blood-2014-02554501

102. Astermark J, Oldenburg J, Pavlova A, Berntorp E, Lefvert A-K, MIBS Study Group. Polymorphisms in the IL10 but not in the IL1beta and IL4 genes are associated with inhibitor development in patients with hemophilia A. Blood. 2006;107(8):3167-3172. doi:10.1182/blood2005-09-3918

103. Astermark J, Oldenburg J, Carlson J, et al. Polymorphisms in the TNFA gene and the risk of inhibitor development in patients with hemophilia A. Blood. 2006;108(12):3739-3745. doi:10.1182/blood-2006-05-024711

104. Astermark J, Wang X, Oldenburg J, Berntorp E, Lefvert A-K, MIBS Study Group. Polymorphisms in the CTLA-4 gene and inhibitor development in patients with severe hemophilia A. J Thromb Haemost JTH. 2007;5(2):263-265. doi:10.1111/j.15387836.2007.02290.x

105. Pavlova A, Delev D, Lacroix-Desmazes S, et al. Impact of polymorphisms of the major histocompatibility complex class II, interleukin-10, tumor necrosis factor-alpha and cytotoxic Tlymphocyte antigen-4 genes on inhibitor development in severe hemophilia A. J Thromb Haemost JTH. 2009;7(12):2006-2015. doi:10.1111/j.1538-7836.2009.03636.x

106. Pinto P, Ghosh K, Shetty S. Immune regulatory gene polymorphisms as predisposing risk factors for the development of factor VIII inhibitors in Indian severe haemophilia A patients. Haemoph Off J World Fed Hemoph. 2012;18(5):794-797. doi:10.1111/j.1365-2516.2012.02845.x

107. Hu G-L, Okita DK, Conti-Fine BM. T cell recognition of the A2 domain of coagulation factor VIII in hemophilia patients and healthy subjects. J Thromb Haemost JTH. 2004;2(11):1908-1917. doi:10.1111/j.1538-7836.2004.00918.x

108. Franchini M, Coppola A, Mengoli C, et al. Blood Group O Protects against Inhibitor Development in Severe Hemophilia A Patients. Semin Thromb Hemost. 2017;43(1):69-74. doi:10.1055/s-0036-1592166

109. Albánez S, Ogiwara K, Michels A, et al. Aging and ABO blood type influence von Willebrand factor and factor VIII levels through interrelated mechanisms. I Thromb Haemost JTH. 2016;14(5):953-963. doi:10.1111/jth.13294

110. Astermark J, Donfield SM, Gomperts ED, et al. The polygenic nature of inhibitors in hemophilia A: results from the Hemophilia Inhibitor Genetics Study (HIGS) Combined Cohort. Blood. 2013;121(8):1446-1454. doi:10.1182/blood-2012-06-434803

111. Repessé Y, Peyron I, Dimitrov JD, et al. Development of inhibitory antibodies to therapeutic factor VIII in severe hemophilia $A$ is associated with microsatellite polymorphisms in the HMOX1 promoter. Haematologica. 2013;98(10):1650-1655. doi:10.3324/haematol.2013.084665 
112. Brusko TM, Wasserfall $\mathrm{CH}$, Agarwal $\mathrm{A}$, Kapturczak $\mathrm{MH}$, Atkinson MA. An integral role for heme oxygenase- 1 and carbon monoxide in maintaining peripheral tolerance by CD4+CD25+ regulatory T cells. J Immunol Baltim Md 1950. 2005;174(9):5181-5186.

113. Choi B-M, Pae H-O, Jeong Y-R, Kim Y-M, Chung H-T. Critical role of heme oxygenase-1 in Foxp3-mediated immune suppression. Biochem Biophys Res Commun. 2005;327(4):1066-1071. doi:10.1016/j.bbrc.2004.12.106

114. Matino D, Gargaro M, Santagostino E, et al. IDO1 suppresses inhibitor development in hemophilia A treated with factor VIII. J Clin Invest. 2015;125(10):3766-3781. doi:10.1172/JCl81859

115. van Baren N, Van den Eynde BJ. Tumoral Immune Resistance Mediated by Enzymes That Degrade Tryptophan. Cancer Immunol Res. 2015;3(9):978-985. doi:10.1158/2326-6066.CIR-150095

116. Dimitrov JD, Dasgupta S, Navarrete A-M, et al. Induction of heme oxygenase-1 in factor VIIIdeficient mice reduces the immune response to therapeutic factor VIII. Blood. 2010;115(13):2682-2685. doi:10.1182/blood-2009-04-216408

117. Delignat S, Gilardin L, Plantier J-L, et al. Role of mannose-ending glycans in the endocytosis and presentation of FVIII to T cell by human and mouse antigen-presenting cells. J Thromb Haemost. 2013;11:207-207.

118. Zakas PM, Brown HC, Knight $\mathrm{K}$, et al. Enhancing the pharmaceutical properties of protein drugs by ancestral sequence reconstruction. Nat Biotechnol. 2017;35(1):35-37. doi:10.1038/nbt.3677

119. Moise L, Song C, Martin WD, Tassone R, De Groot AS, Scott DW. Effect of HLA DR epitope deimmunization of Factor VIII in vitro and in vivo. Clin Immunol Orlando Fla. 2012;142(3):320-331. doi:10.1016/j.clim.2011.11.010

120. Scott DW. Inhibitors - cellular aspects and novel approaches for tolerance. Haemoph Off J World Fed Hemoph. 2014;20 Suppl 4:80-86. doi:10.1111/hae.12407

121. Macauley MS, Pfrengle F, Rademacher C, et al. Antigenic liposomes displaying CD22 ligands induce antigen-specific B cell apoptosis. J Clin Invest. 2013;123(7):3074-3083. doi:10.1172/JCI69187

122. Jellusova J, Nitschke L. Regulation of B cell functions by the sialic acid-binding receptors siglec-G and CD22. Front Immunol. 2011;2:96. doi:10.3389/fimmu.2011.00096

123. Moghimi B, Sack BK, Nayak S, Markusic DM, Mah CS, Herzog RW. Induction of tolerance to factor VIII by transient co-administration with rapamycin. J Thromb Haemost JTH. 2011;9(8):1524-1533. doi:10.1111/j.1538-7836.2011.04351.x

124. Maldonado RA, LaMothe RA, Ferrari JD, et al. Polymeric synthetic nanoparticles for the induction of antigen-specific immunological tolerance. Proc Natl Acad Sci U S A. 2015;112(2):E156-165. doi:10.1073/pnas.1408686111

125. Joly MS, Martin RP, Mitra-Kaushik S, et al. Transient low-dose methotrexate generates B regulatory cells that mediate antigen-specific tolerance to alglucosidase alfa. J Immunol Baltim Md 1950. 2014;193(8):3947-3958. doi:10.4049/jimmunol.1303326 
126. Liu CL, Ye P, Lin J, Djukovic D, Miao CH. Long-term tolerance to factor VIII is achieved by administration of interleukin-2/interleukin-2 monoclonal antibody complexes and low dosages of factor VIII. J Thromb Haemost JTH. 2014;12(6):921-931. doi:10.1111/jth.12576

127. Kim $\mathrm{YC}$, Zhang $\mathrm{A}-\mathrm{H}$, Su $\mathrm{Y}$, et al. Engineered antigen-specific human regulatory $\mathrm{T}$ cells: immunosuppression of FVIII-specific T- and B-cell responses. Blood. 2015;125(7):1107-1115. doi:10.1182/blood-2014-04-566786

128. Gupta N, Culina S, Meslier Y, et al. Regulation of immune responses to protein therapeutics by transplacental induction of $\mathrm{T}$ cell tolerance. Sci Transl Med. 2015;7(275):275ra21. doi:10.1126/scitransImed.aaa1957

129. Rawle FE, Pratt KP, Labelle A, Weiner HL, Hough C, Lillicrap D. Induction of partial immune tolerance to factor VIII through prior mucosal exposure to the factor VIII C2 domain. J Thromb Haemost JTH. 2006;4(10):2172-2179. doi:10.1111/j.1538-7836.2006.02118.x

130. Sherman A, Su J, Lin S, Wang X, Herzog RW, Daniell H. Suppression of inhibitor formation against FVIII in a murine model of hemophilia $A$ by oral delivery of antigens bioencapsulated in plant cells. Blood. 2014;124(10):1659-1668. doi:10.1182/blood-2013-10-528737

131. Antoni G, Oudot-Mellakh T, Dimitromanolakis A, et al. Combined analysis of three genomewide association studies on VWF and FVIII plasma levels. BMC Med Genet. 2011;12:102. doi:10.1186/1471-2350-12-102

132. Swystun LL, Notley C, Georgescu I, James PD, Lillicrap D. The Endothelial Lectin Receptor CLEC4M Internalizes Factor VIII and Von Willebrand Factor Via a Clathrin-Coated Pit-Dependent Mechanism. Blood. 2013;122(21). 


\section{Legends to figures}

Figure $1^{1}$. Initiation of the anti-FVIII immune response. Therapeutic exogenous FVIII is captured by APCs that cleave FVIII into small peptides in the endosomal compartment. FVIII-derived peptides associate with molecules of MHC class II. Complexes of FVIIIderived peptide and MHC class II molecules are exposed at the surface of APCs and are presented to naïve CD4 T cells. The recognition of FVIII-derived peptide by the TCR of the T lymphocytes provides the first activation signal (signal 1), interactions of co-stimulation molecules and ligands at the surface of T cells and APCs provide a second signal (signal 2), a third signal is mediated by soluble pro-inflammatory stimuli such as cytokines (signal 3). The three signals are required to get the full activation of naïve $\mathrm{T}$ cells and differentiation into effector T cells. Naïve B cells that have internalized FVIII through their BCR, present CMH II/peptide complexes to the activated FVIII-specific $\mathrm{T}$ cells. The formation of the T/B cell synapse triggers intracellular signaling that leads to the differentiation of follicular B cells either into memory B cells or plasma cells.

\footnotetext{
${ }^{1}$ Abbreviations: PAMPS, pathogen-associated molecular patterns; TFs, tissue-factors; PRR, pattern recognition receptors; TCR, T-cell receptor.
} 
Table 1. Endocytic receptors for FVIII ${ }^{2}$

\begin{tabular}{|c|c|c|c|c|}
\hline Receptor & FVIII binding & Catabolism & $\begin{array}{l}\text { Endocytosis leading to } \\
\text { peptide presentation* }\end{array}$ & References \\
\hline LRP-1 & $\begin{array}{l}\text { Light chain (inhibited by } \\
\text { VWF) } \\
\text { A2/A3 domain of } \\
\text { activated FVIII }\end{array}$ & Yes & No & $34,37-40,48$ \\
\hline LDL-R & Specific site unknown & Yes (in mice) & No & 36,47 \\
\hline HSPG & A2 domain & $\begin{array}{l}\text { Yes in mice } \\
\text { (LRP-1 } \\
\text { dependent and } \\
\text { LRP-1 } \\
\text { independent) }\end{array}$ & No & 41 \\
\hline ASGPR & $\begin{array}{l}\text { Desialylated B-domain } \\
\text { associated glycans }\end{array}$ & Yes (in mice) & No & 50,51 \\
\hline Siglec-5 & Specific site unknown & $\begin{array}{l}\text { Yes (in mice } \\
\text { expressing } \\
\text { human Siglec- } \\
\text { 5) }\end{array}$ & unknown & 52 \\
\hline $\begin{array}{l}\text { CD206 } \\
\text { (MMR) }\end{array}$ & $\begin{array}{l}\text { Exposed mannose glycans } \\
\text { at Asn239 and Asn2118 } \\
\text { (inhibited by VWF) }\end{array}$ & No (in mice) & Yes & 29,55 \\
\hline CLEC4M & High mannose glycans & No & No & $66,131,132$ \\
\hline
\end{tabular}

* In in vitro model using mouse or human DCs

2 Abbreviations: LRP-1, low-density lipoprotein related receptor-1; LDL-R, low-density lipoprotein receptor; HSPG, heparan sulfate proteoglycan; ASGPR, asialoglycoprotein receptor; Siglec-5, sialic-acid binding immunoglobulin-like lectin-5; MMR, macrophage mannose receptor; CLEC4M, C-type lectin domain family 4 member $\mathrm{M}$. 
Table 2. Therapeutic strategy to prevent the development of inhibitors in preclinical model $^{3}$

\begin{tabular}{|c|c|c|c|c|}
\hline Target & $\begin{array}{l}\text { Therapeutic } \\
\text { strategy }\end{array}$ & Mechanism of action & FVIII-specific & References \\
\hline $\begin{array}{l}\text { APCs (Endocytosis } \\
\text { of FVIII) }\end{array}$ & $\begin{array}{l}\text { Modification of FVIII } \\
\text { structure }\end{array}$ & $\begin{array}{l}\text { Prevention of FVIII } \\
\text { capture by APCS }\end{array}$ & Yes & 69,81 \\
\hline $\begin{array}{l}\text { T cells/ APCs } \\
\text { synapse (signal } 1 \text { ) }\end{array}$ & $\begin{array}{l}\text { Prediction of T cell } \\
\text { epitope and design } \\
\text { of mutated FVIII }\end{array}$ & $\begin{array}{l}\text { De-immunization by } \\
\text { prevention of HLA-DR } \\
\text { mediated interactions }\end{array}$ & Yes & 119 \\
\hline B cells & $\begin{array}{l}\text { FVIII and CD22L } \\
\text { coated liposomal } \\
\text { nanoparticles }\end{array}$ & $\begin{array}{l}\text { Suppression of } B \text { cell } \\
\text { response by } \\
\text { engagement of } C D 22\end{array}$ & Yes & 121 \\
\hline \multirow[t]{5}{*}{$\begin{array}{l}\text { Tolerance } \\
\text { induction }\end{array}$} & Rapamycin & $\begin{array}{l}\text { Inhibition of II-2 } \\
\text { signalization, } \\
\text { emergence of } \\
\text { regulatory T cells }\end{array}$ & $\begin{array}{l}\text { No/ } \\
\text { Yes, if formulated in } \\
\text { FVIII containing } \\
\text { nanoparticles }\end{array}$ & 123,124 \\
\hline & $\begin{array}{l}\text { Methotrexate } \\
\text { (Single low dose } \\
\text { regimen) }\end{array}$ & $\begin{array}{l}\text { Induction of II-10 and } \\
\text { TGF- } \beta \text { secreting } \\
\text { regulatory B cells }\end{array}$ & $\begin{array}{l}\text { Not tested in } \\
\text { preclinical model of HA } \\
\text { (described as antigen } \\
\text { specific) }\end{array}$ & 125 \\
\hline & $\begin{array}{l}\text { II-2/ anti-II-2 } \\
\text { complexes }\end{array}$ & Emergence of Tregs & No & 126 \\
\hline & $\begin{array}{l}\text { Materno-foetal } \\
\text { transfer of } A 2 / C 2 \\
\text { domain of FVIII } \\
\text { fused to Fc fragment } \\
\text { of IgG1 }\end{array}$ & $\begin{array}{l}\text { Induction of central } \\
\text { and peripheral } \\
\text { tolerance by passive } \\
\text { transfer of } \mathrm{A} 2 \text { and } \mathrm{C} 2 \\
\text { from the mother to } \\
\text { the foetus }\end{array}$ & Yes & 128 \\
\hline & $\begin{array}{l}\text { Administration of } \\
\text { bio-encapsulated } \\
\text { FVIII fragments } \\
\text { fused to the B } \\
\text { subunit of the CTB }\end{array}$ & $\begin{array}{l}\text { Induction of tolerance } \\
\text { through mucosal } \\
\text { route, emergence of } \\
\text { Tregs }\end{array}$ & Yes & 130 \\
\hline
\end{tabular}

\footnotetext{
${ }^{3}$ Abbreviations: APCs, antigen-presenting cells; HLA-DR, Human Leukocyte Antigen - antigen D Related; CD22, cluster of differentiation-22; Il-2, interleukin-2; Il-10, interleukin-10; TGF- $\beta$, transforming growth factor beta; Tregs, regulatory T cells; Fc, Fc- Fragment of IgG; CTB, Cholera toxin B.
} 